\title{
Ahmet Yemenicioğlu \\ Control of polyphenol oxidase in whole potatoes by low temperature blanching
}

Received: 20 August 2001 / Revised version: 18 October 2001 / Published online: 11 January 2002

(C) Springer-Verlag 2002

\begin{abstract}
Russet Burbank potatoes can be blanched up to $60 \mathrm{~min}$ at $50{ }^{\circ} \mathrm{C}$ without any loss in firmness and without appearance of browning on their peels, eyes or infected areas. Low temperature blanching (LTB) for 45 min did not cause a significant reduction in crude polyphenol oxidase (PPO) activity (12\%). However, when heating time was extended to $60 \mathrm{~min}$, the activity and specific activity of the enzyme were reduced by $27-45 \%$ and $22-43 \%$ respectively. The remaining enzyme extracted from heated potatoes was partially purified 3.3-3.75-fold by 0-95\% ammonium sulphate precipitation and dialysis, and its kinetic parameters were determined. The comparison of the kinetic parameters of PPO in control $\left(K_{\mathrm{m}}=10.3 \mathrm{mM}\right.$ and $\left.V_{\max } / K_{\mathrm{m}}=0.15\right)$ and in 60 min heated potatoes $\left(K_{\mathrm{m}}=13 \mathrm{mM}\right.$ and $\left.V_{\max } / K_{\mathrm{m}}=0.054\right)$ indicated the reduced affinity of the remaining enzyme to its substrate. Thus, LTB at $50{ }^{\circ} \mathrm{C}$ for 60 min not only inactivated part of the PPO activity but also reduced the kinetic capacity of remaining enzyme. Extending heating time to $75 \mathrm{~min}$ caused the appearance of slight browning on the peels and eyes of potatoes and reduced their firmness. The observed browning was due to the sharp drop in the $K_{\mathrm{m}}$ that caused the activation of the PPO. Heating at $50{ }^{\circ} \mathrm{C}$ did not affect lipoxygenase activity, but the $K_{\mathrm{m}}$ of the enzyme dropped from 0.4 to $0.15 \mathrm{mM}$ and the enzyme became kinetically more reactive at low substrate concentrations. Covalently bound pectin methylesterase considerably activated (38\%) by heating and this caused the drop of $\mathrm{pH}$ in potato tissues.
\end{abstract}

Keywords Blanching $\cdot$ Potatoes $\cdot$ Polyphenol oxidase · Lipoxygenase $\cdot$ Pectin methylesterase

\footnotetext{
A. Yemenicioğlu (®)

Associate Professor of Food Science,

İzmir Institute of Technology, Department of Food Engineering,

Faculty of Engineering, 35437 Gülbahçe Köyü Urla,

İzmir, Turkey

e-mail: ayemen@likya.iyte.edu.tr

Tel.: +90-232-4986292, Fax: +90-232-4986355
}

\section{Introduction}

Enzymatic browning catalysed by polyphenol oxidase (PPO) is a major problem in the minimal processing of prepeeled or sliced potatoes. To eliminate this problem, sulphites have been used successfully, but due to their adverse health effects, various alternative chemicals such as ascorbic or erythorbic acids, citric acid, L-cysteine, etc. have been employed in place of sulphites to control browning $[1,2,3]$. Although, these chemicals retard the browning and extend the shelf life of processed potatoes, they are less effective than sulphites. Therefore, to obtain the desired shelf life, many workers have suggested the application of sulphite alternatives in combination with some supportive treatments. Some of these treatments include: removing PPO and phenolic-rich surface tissues of pre-peeled potatoes by lye digestion before inhibitor application [4], packaging under nitrogen atmosphere in some acidic cover solutions [1], reducing inhibitor solution $\mathrm{pH}$ by inorganic acids [2] or dipping into heated inhibitor solutions [5].

Low temperature blanching (LTB) of whole potatoes prior to minimal processing may also be a potential treatment to control enzymatic browning in sliced or prepeeled potatoes and to support sulphite alternatives. LTB between $40-50{ }^{\circ} \mathrm{C}$ was applied to whole apples by Kim et al. [6] and it was reported to reduce the tendency of browning in apple slices successfully. These workers did not investigate the effect of LTB on PPO activity. However, assuming that the enzyme cannot be inactivated at such low heating temperatures, they attributed the reduced browning rate in apple slices to the in situ modification of PPO's kinetic properties during heating. Valle et al. [7] also applied LTB to apple pieces between 40 and $65{ }^{\circ} \mathrm{C}$ prior to minimal processing and effectively reduced their PPO activity (30-87\%). Yemenicioğlu et al. [8] investigated the heat stability of PPO from six different apple cultivars in buffer solutions and reported that the enzyme was extremely heat stable between 68 and $78{ }^{\circ} \mathrm{C}$ and activated by heat. Thus, it seems that the in situ effect of low temperatures on PPO enzyme is different and cannot be explained simply by thermal inactivation. 
Compared to apples, potatoes are more resistant to heat injury. Therefore, LTB of whole potatoes has been applied to improve their firmness and to increase their resistance to physical breakdown during further processing [9]. Also, LTB may be applied to enhance the storability of potatoes and to prevent their sprouting and spoilage due to invasion by bacterial and fungal pathogens [10]. This study was carried out primarily to investigate the effects of LTB on the activity and kinetic properties of potato PPO. The effects of heating on lipoxygenase (LOX) and pectin methylesterase (PME) were also investigated, to estimate possible changes in the flavour and firmness of heated tubers. The results of this work are a contribution to the studies on extending the shelf life of minimally processed potatoes.

\section{Material and methods}

Materials. Russet Burbank potatoes were obtained from a potato processing plant in Bolu, Turkey. The average length, thickness and weight of potatoes were $109.2 \pm 6.1 \mathrm{~mm}, 45.9 \pm 4.6 \mathrm{~mm}$ and $164.9 \pm 22.7 \mathrm{~g}$ respectively. The dialysis tubing (D-9527, prepared as described in product information), citrus pectin (galacturonic acid content $79 \%$, methoxy content $8 \%$ ), linoleic acid (99\%) and bovine serum albumin were purchased from Sigma. Ammonium sulphate (for biochemistry) and catechol were purchased from Merck. All the other chemicals were reagent grade.

Heating temperature. For the determination of a suitable heating temperature, the potatoes were put into perforated cloth sacks and blanched in tap water at 50,55 or $60{ }^{\circ} \mathrm{C}$ for 45,60 or 75 min using a circulating waterbath (Polyscience, Model 71). In all studies, almost $2 \mathrm{~kg}$ potatoes were blanched in 251 tap water. The heating profiles of several potatoes were monitored by placing thermocouples in their geometric center and by using a portable temperature recorder (Cole Parmer, DualLogR). The blanched samples were cooled in cold water, drained, halved longitudinally and examined for their firmness by using a Nippon fruit hardness tester-5 $\mathrm{kg}$ (Model FHR-5) equipped with a cone type tip (base diameter, $12 \mathrm{~mm}$; height, $10 \mathrm{~mm}$ ). The penetrations were carried out on the cut surfaces of each potato half at 18 points $(\cong 1 \mathrm{~cm}$ spaced points designed to form three rows and six columns). After heating, cooling and halving, some of the potatoes were left for almost $1 \mathrm{~h}$ at room temperature and they were examined carefully to detect possible browning due to heat injury.

Enzyme extraction and partial purification. Acetone powder was used as enzyme source in this study. For the preparation of acetone powder, $200 \mathrm{~g}$ sliced cold potatoes were added to a Waring blender containing $300 \mathrm{ml}$ acetone at $-18{ }^{\circ} \mathrm{C}$ and $1 \mathrm{~g}$ polyvinylpolypyrrolidone (PVPP). The mixture was homogenised for 2 min and filtered through a Buchner funnel containing a Whatman No 1 filter paper. This procedure was repeated twice using $200 \mathrm{ml}$ cold acetone and the powder obtained was left overnight to evaporate the acetone. This powder was kept in a deep freezer and used in all enzyme extractions. For enzyme extraction, two different extraction mixtures were used. Extraction mixture 1 (EM1) was prepared by mixing $2 \mathrm{~g}$ acetone powder, $0.4 \mathrm{~g}$ PVPP and $50 \mathrm{ml}$ of cold $8.8 \% \mathrm{NaCl}$ solution. Extraction mixture 2 (EM2) was prepared by mixing $2.5 \mathrm{~g}$ acetone powder, $0.5 \mathrm{~g}$ PVPP and $60 \mathrm{ml}$ of cold $8.8 \%$ $\mathrm{NaCl}$ solution. The extractions were carried out under magnetic stirring for $3 \mathrm{~h}$ at $4{ }^{\circ} \mathrm{C}$ and the slurries obtained were filtered through six layers of cheese cloth and centrifuged at $4{ }^{\circ} \mathrm{C}$ and $11,000 \mathrm{~g}$ for $20 \mathrm{~min}$. These crude extracts contained soluble+ionically bound enzymes. Covalently bound enzyme extracts were prepared for the assay of PME enzyme activity only. For this purpose the slurries obtained after enzyme extraction were centri- fuged at $1200 \mathrm{~g}$ for $20 \mathrm{~min}$ and the collected pellets were resuspended in cold deionised water.

For partial purification the following procedure was applied unless otherwise stated. The enzyme extracts were slowly brought to $0-95 \%$ saturation with solid $\left(\mathrm{NH}_{4}\right)_{2} \mathrm{SO}_{4}$, mixed gently for $1 \mathrm{~h}$ at $4{ }^{\circ} \mathrm{C}$ and then centrifuged at $4{ }^{\circ} \mathrm{C}$ and $15,000 \mathrm{~g}$ for $45 \mathrm{~min}$. The collected pellets were dissolved in cold deionised water and dialysed for $24 \mathrm{~h}$ at $4{ }^{\circ} \mathrm{C}$ against $2 \times 20001$ deionised water.

Enzyme assays. A Shimatzu (Model 1601) spectrophotometer, equipped with a constant temperature cell holder, was used in spectrophotometric assays. All the assays were conducted at $30{ }^{\circ} \mathrm{C}$ constant temperature. PPO activity was determined at $420 \mathrm{~nm}$ by using the following reaction mixtures: reaction mixture 1 (RM1), $2 \mathrm{ml}$ of $0.01 \mathrm{M}$ sodium phosphate buffer at $\mathrm{pH} 7.0,0.2 \mathrm{ml}$ of $0.25 \mathrm{M}$ catechol and $0.3 \mathrm{ml}$ of enzyme extract; and reaction mixture 2 (RM2), $2 \mathrm{ml}$ of $0.01 \mathrm{M}$ Na-phosphate buffer at $\mathrm{pH} 7.0,0.4 \mathrm{ml}$ of $0.06 \mathrm{M}$ catechol and $0.2 \mathrm{ml}$ enzyme extract. LOX activity was determined at $234 \mathrm{~nm}$ using the following reaction mixture: $2 \mathrm{ml}$ of $0.01 \mathrm{M}$ sodium phosphate buffer ( $\mathrm{pH} 7.0), 0.05 \mathrm{ml}$ linoleic acid solution prepared with Tween-20 as described in Rackis et al. [11] and $0.1 \mathrm{ml}$ enzyme extract. This reaction mixture was named as RM1a or RM1b when the concentrations of linoleic acid were 14.3 or $18.9 \mathrm{mM}$, respectively. PME activity was assayed at $620 \mathrm{~nm}$ as described in Hagerman and Austin [12]. The reaction mixture contained $2 \mathrm{ml}$ of $0.35 \%$ pectin solution prepared in $0.1 \mathrm{~N} \mathrm{NaCl}, 0.3 \mathrm{ml}$ of $0.01 \%(\mathrm{w} / \mathrm{v})$ bromothymol blue prepared in $0.003 \mathrm{M}$ sodium phosphate buffer at $\mathrm{pH} 7.5$, and $0.3 \mathrm{ml}$ enzyme extract. The activity of PME was also assayed by the titrimetric method given in Yemenicioğlu and Cemeroğlu [13]. The reaction mixture contained $4 \mathrm{ml}$ (or $8 \mathrm{~g}$ suspension in the assay for covalently bound PME) enzyme extract and $18 \mathrm{ml}$ of $0.35 \%$ pectin solution prepared in $0.1 \mathrm{~N}$ $\mathrm{NaCl}$. The $\mathrm{pH}$ of reactants were brought to 7.5 with $0.1 \mathrm{~N} \mathrm{NaOH}$ solution before each assay and the titrations were carried out manually for $10 \mathrm{~min}$ by using $0.01 \mathrm{~N}$ (or $0.003 \mathrm{~N}$ in the assay for covalently bound PME) $\mathrm{NaOH}$ solution. The titrimetric assays were conducted in a double walled, magnetically stirred cell connected to a circulating water bath working at $30^{\circ} \mathrm{C}$. The activities of enzymes were expressed as units (U) and units per milligram protein. In spectrophotometric assays, $1 \mathrm{U}$ was defined as 0.001 change in absorbance $/ \mathrm{min} / \mathrm{ml}$ enzyme extract. In titrimetric assays, $1 \mathrm{U}$ was defined as the number of micromoles carboxyl liberated in $10 \mathrm{~min}$ per millilitre (or per gram for the covalently bound PME) of enzyme extract. An average of 10 or 15 measurements were used to find crude enzyme activity when no purification was applied. In partial purification studies an average of 3-5 measurements were used to find crude and partially purified enzyme activities.

Enzyme kinetics. Michaelis constants $\left(K_{\mathrm{m}}\right)$ and maximum velocities $\left(V_{\max }\right)$ of enzymes were determined using the double reciprocal plots. To reduce the final concentrations of substrates in cuvettes into the neighbourhood of the $K_{\mathrm{m}}$ of PPO and LOX, the concentrations of catechol $(0.025-1 \mathrm{M})$ and linoleic acid (2.84-18.6 mM) solutions were selected carefully. At each substrate concentration, 4-5 and 5-7 measurements were conducted at high and low substrate concentrations, respectively.

$\mathrm{pH}$ and conductivity measurements. The $\mathrm{pH}$ and conductivities of extracts obtained from heated potatoes were determined, to detect the action of PME and electrolyte leakage due to membrane damage, respectively. For the preparation of extracts, $5 \mathrm{~g}$ ground tissue, obtained from the centre of a single potato, was mixed with $350 \mathrm{ml}$ of deionised water. The mixture was stirred for $5 \mathrm{~min}$ with a magnetic stirrer and filtered through six layers of cheese cloth. For each heating time, this procedure was applied to at least five potatoes. The measurements were carried out by a WTW-multi parameter (Inolab, Level-3).

Protein content. Protein was determined by the method of Lowry using bovine serum as a standard [14]. The protein standards of crude and partially purified extracts were prepared in $8.8 \% \mathrm{NaCl}$ solution and deionised water, respectively. All assays were carried out at least five times. 
Table 1 Determination of time/temperature limits for low temperature blanching

\begin{tabular}{llllll}
\hline Sample number & Temperature $\left({ }^{\circ} \mathrm{C}\right)$ & Time $(\mathrm{min})$ & Firmness $(\mathrm{kg})$ & Number of penetrations & Browning \\
\hline 1 (Control) & - & - & $2.52 \pm 0.12$ & 719 & - \\
1 & 50 & 45 & $2.53 \pm 0.12$ & 362 & No \\
1 & 50 & 60 & $2.53 \pm 0.12$ & 362 & No \\
1 & 55 & 45 & $2.48 \pm 0.10$ & 362 & Slightly \\
1 & 55 & 60 & $2.51 \pm 0.10$ & 362 & Slightly \\
1 & 60 & 45 & $2.45 \pm 0.11$ & 362 & Apparent \\
1 & 60 & 60 & $2.44 \pm 0.13$ & 362 & Apparent \\
$2($ Control) & - & - & $2.48 \pm 0.12$ & 575 & - \\
2 & 50 & 45 & $2.50 \pm 0.10$ & 575 & No \\
2 & 50 & 60 & $2.50 \pm 0.12$ & 575 & No \\
2 & 50 & 75 & $2.44 \pm 0.14$ & 575 & Slightly \\
3 (Control) $^{\mathrm{a}}$ & - & - & $2.54 \pm 0.13$ & 160 & - \\
3 & 50 & 60 & $2.57 \pm 0.13$ & 160 & No \\
3 & 50 & 90 & $2.61 \pm 0.11$ & 160 & No \\
4 (Control) $^{\mathrm{a}}$ & - & - & $2.47 \pm 0.13$ & 128 & - \\
4 & 50 & 45 & $2.49 \pm 0.12$ & 128 & No \\
4 & 50 & 60 & $2.52 \pm 0.12$ & 128 & No \\
4 & 50 & 90 & $2.57 \pm 0.11$ & 128 & Slightly \\
4 & 50 & 120 & $2.52 \pm 0.10$ & 128 & \\
\hline
\end{tabular}

a The results obtained for local cultivars

\section{Results and Discussion}

Heating temperature

Heating at $55^{\circ} \mathrm{C}$ and $60{ }^{\circ} \mathrm{C}$ caused slight and obvious reductions in the internal firmness of potatoes, respectively (Table 1). Also, after cooling, various degrees of browning were observed on peels, eyes, infected areas and injured areas of these potatoes. In contrast, heating at $50{ }^{\circ} \mathrm{C}$ for 45 or $60 \mathrm{~min}$ increased the internal firmness of potatoes slightly and caused no browning. This result was confirmed by repeating the heating studies at $50{ }^{\circ} \mathrm{C}$ with some new samples (No: 2). Also, this time we tried 75 min heating. However, 15 min more heating at this temperature reduced the internal firmness of potatoes and caused slight browning on their peels. Thus, for Russet Burbank potatoes used in this study, the upper limit of heating at $50{ }^{\circ} \mathrm{C}$ was between 60 and $75 \mathrm{~min}$. The effect of heating at $50{ }^{\circ} \mathrm{C}$ was also tested for two local cultivars (from Ödemiş, İzmir). In these potatoes, the firming effect pronounced and the appearance of browning and/or softening was not observed before $90 \mathrm{~min}$. Because of the differences in heating conditions, it is hard to compare our results with those of the previously conducted studies. However, the firming effect of $50{ }^{\circ} \mathrm{C}$ heating was also reported by Mittal [15] who heated whole potatoes at five different temperatures between 30 and $90{ }^{\circ} \mathrm{C}$. The same author reported extensive thermal softening above $60{ }^{\circ} \mathrm{C}$. Ranganna et al. [10] investigated hot water dipping of whole potatoes to enhance their storability and reported heat damage above $57.5^{\circ} \mathrm{C}$. In contrast, these researchers detected no signs of heat injury in potatoes heated at $57.5^{\circ}$ or $52.5{ }^{\circ} \mathrm{C}$ for $30 \mathrm{~min}$. Also, in their detailed review, Andersson et al. [9] reported that no reduction in potato tensile strength (minimum longitudinal stress required to pull a section of po- tato tuber tissue apart) or denaturation of cell wall membranes occurred when potatoes were heated at $50{ }^{\circ} \mathrm{C}$ or at lower temperatures. Thus, we decided that $50{ }^{\circ} \mathrm{C}$ would be a suitable temperature for our purpose.

\section{Effect of heating on PPO}

The effect of LTB at $50{ }^{\circ} \mathrm{C}$ on remaining PPO activity in potatoes was compared for different extraction and assay conditions (Table 2). When crude enzyme extracts were prepared using EM1 and assayed using RM1, in which the final substrate concentration $(20 \mathrm{mM})$ was higher than the $K_{\mathrm{m}}$ of control, no significant inactivation occurred in potatoes heated for $45 \mathrm{~min}$. Therefore, we concentrated on 60 min heating which caused $27 \%$ loss of PPO activity in potatoes under the same extraction and assay conditions. When enzyme was extracted using EM2 and assayed using RM2, in which final substrate concentration $(9.2 \mathrm{mM})$ was close to the $K_{\mathrm{m}}$ of control, more than $40 \%$ inactivation occurred in the activity and specific activity of crude PPO. The observed increase in percentage inactivation was apparently due to the higher and lower PPO activity in control and heated potatoes under the changed conditions, respectively. During heating, it took almost 45 and 60 min to reach 49 and $50{ }^{\circ} \mathrm{C}$ at the centre of potatoes, respectively (Fig. 1). Thus, it is apparent that partial PPO inactivation occurred in $15 \mathrm{~min}$ when the whole potato temperature was between 49 and $50{ }^{\circ} \mathrm{C}$. The inactivation of part of the PPO activity at such a low heating temperature was not surprising. This is because potatoes contain multiple forms of PPO enzyme [16], of which some are extremely heat labile [17].

To obtain more information about the kinetic characteristics of remaining PPO in heated potatoes, we determined the $K_{\mathrm{m}}$ and $V_{\max }$ of partially purified enzymes 
Table 2 Activity and kinetic parameters of polyphenol oxidase from control and low temperature blanched potatoes. EM Extraction mixture, $R M$ reaction mixture

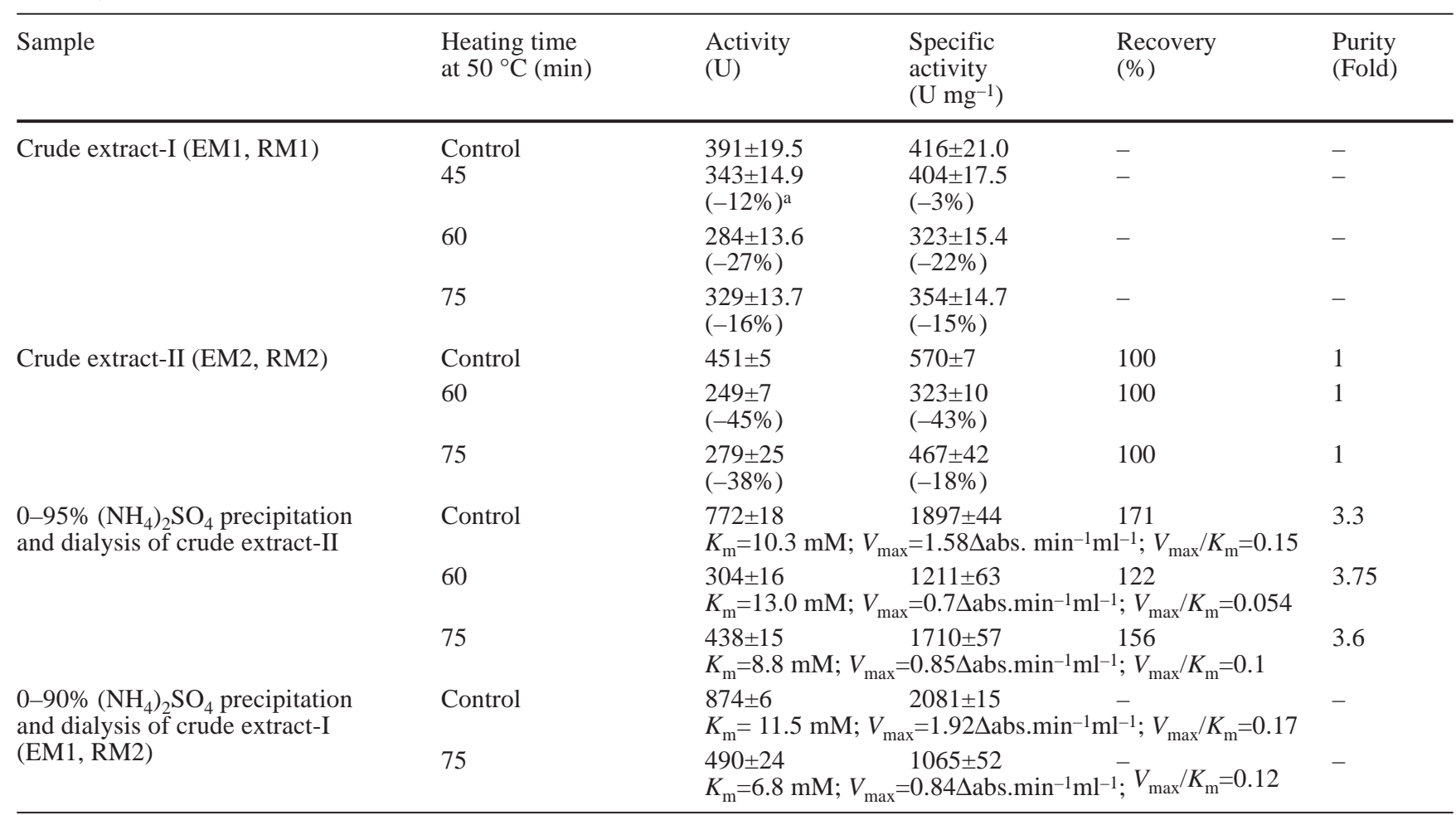

a Indicates the percentage change in activity or specific activity as compared to the corresponding control

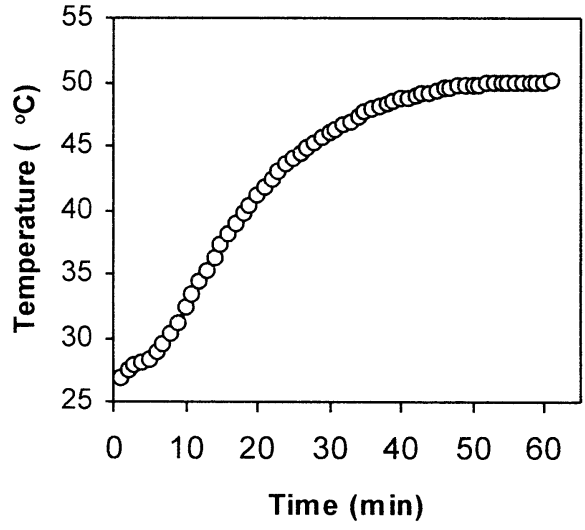

Fig. 1 Heat penetration curve of potatoes at $50{ }^{\circ} \mathrm{C}$

(Table 2). LTB potatoes at $50{ }^{\circ} \mathrm{C}$ for 60 min caused some desired changes in the kinetic parameters of the enzyme. The increase in the $K_{\mathrm{m}}$ value and the reduction in the $V_{\max } / K_{\mathrm{m}}$ value clearly indicated the reduced affinity of the residual enzyme to its substrate (Fig. 2). Thus, LTB at $50{ }^{\circ} \mathrm{C}$ for 60 min not only inactivated part of the PPO activity, but also reduced the kinetic capacity of the remaining enzyme. These positive effects of LTB may increase the shelf life of minimally processed potatoes by reducing their tendency of browning and/or by delaying

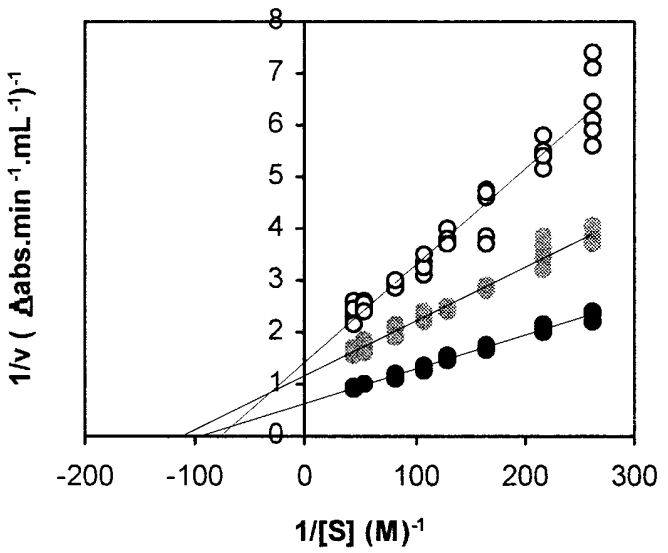

Fig. 2 Double reciprocal plots for partially purified polyphenol oxidase from control and low temperature blanched potatoes. Grey circles $50{ }^{\circ} \mathrm{C} / 75 \mathrm{~min}$, white circles $50^{\circ} \mathrm{C} / 60 \mathrm{~min}$, black circles control

the exhaustion of added antioxidants such as ascorbic acid and its derivatives. Our results confirmed the assumptions of Kim et al. [6] who subjected whole apples to LTB at 40,45 and $50{ }^{\circ} \mathrm{C}$ and obtained less tendency of browning in apple slices. These researchers did not investigate the effect of LTB on PPO activity, but attributed the reduced browning rate in apple slices to the in situ kinetic changes in the PPO enzyme. The change occurred in the kinetic properties of enzyme at a relatively low temperature may be explained simply by the inacti- 
Table 3 Activity and kinetic parameters of lipoxygenase from control and low temperature blanched potatoes. EM Extraction mixture, $\mathrm{RM}$ reaction mixture

\begin{tabular}{|c|c|c|c|c|c|}
\hline Sample & $\begin{array}{l}\text { Heating time } \\
\text { at } 50^{\circ} \mathrm{C}(\mathrm{min})\end{array}$ & $\begin{array}{l}\text { Activity } \\
\text { (U) }\end{array}$ & $\begin{array}{l}\text { Specific } \\
\text { activity } \\
\left(\mathrm{U} \mathrm{mg}^{-1}\right)\end{array}$ & $\begin{array}{l}\text { Recovery } \\
(\%)\end{array}$ & $\begin{array}{l}\text { Purity } \\
\text { (Fold) }\end{array}$ \\
\hline \multirow[t]{4}{*}{ Crude extract-I (EM1, RM1a) } & Control & $4853 \pm 220$ & $5168 \pm 234$ & - & - \\
\hline & 45 & $\begin{array}{l}4938 \pm 218 \\
(+2 \%)^{\mathrm{a}}\end{array}$ & $\begin{array}{l}5816 \pm 256 \\
(+13 \%)\end{array}$ & - & - \\
\hline & 60 & $\begin{array}{l}4395 \pm 180 \\
(-9 \%)\end{array}$ & $\begin{array}{l}5000 \pm 205 \\
(-3 \%)\end{array}$ & - & - \\
\hline & 75 & $\begin{array}{l}4559 \pm 189 \\
(-6 \%)\end{array}$ & $\begin{array}{l}4907 \pm 204 \\
(-5 \%)\end{array}$ & - & - \\
\hline Crude extract-II (EM2, RM1b) & $\begin{array}{l}\text { Control } \\
60\end{array}$ & $\begin{array}{l}5213 \pm 125 \\
4718 \pm 166 \\
(-9 \%)\end{array}$ & $\begin{array}{l}6591 \pm 158 \\
6135 \pm 216 \\
(-7 \%)\end{array}$ & $\begin{array}{l}100 \\
100\end{array}$ & $\begin{array}{l}1 \\
1\end{array}$ \\
\hline \multirow{2}{*}{$\begin{array}{l}0-95 \%\left(\mathrm{NH}_{4}\right)_{2} \mathrm{SO}_{4} \\
\text { precipitation and dialysis of } \\
\text { crude extract-II }\end{array}$} & Control & \multicolumn{4}{|c|}{$K_{\mathrm{m}}=0.4 \mathrm{mM} ; V_{\max }=10.1 \Delta$ abs. $\mathrm{min}^{-1} \mathrm{ml}^{-1} ; V_{\max } / K_{\mathrm{m}}=25.3$} \\
\hline & 60 & \multicolumn{4}{|c|}{$K_{\mathrm{m}}=0.15 \mathrm{mM} ; V_{\max }=5.0 \Delta$ abs. $\mathrm{min}^{-1} \mathrm{ml}^{-1} ; V_{\max } / K_{\mathrm{m}}=33.3$} \\
\hline
\end{tabular}

${ }^{a}$ Indicates the percentage change in activity or specific activity as compared to the corresponding control

vation of heat labile fractions of PPO, which have high substrate specificity. The modification of the enzyme's quaternary or tertiary structures during heating may also be possible. In the literature, data related to the effects of low temperatures on PPO configuration are scarce. However, Vamos-Vigyazo [16] have reported that oligomeric forms of PPO are generally more active than its monomeric forms, and that these forms may transform each other by association-dissociation reactions. This kind of modification in oligomeric enzymes is observed very frequently when relatively low pressures (100 and $200 \mathrm{MPa}$ ) are applied to them during processing [18, 19]. High pressure disrupts hydrophobic and ion-pair bonds between the subunits of oligomeric enzymes and causes depolymerisation [19]. Cho and Ahn [20] showed that potato PPO may exist as a dimer of identical subunits $(2 \times 43 \mathrm{kDa})$. Thus, it is also likely that mild heating caused the dissociation of some oligomeric PPO forms to less active monomers with a mechanism similar to that of high pressure processing. Further research is needed to reveal the mechanisms of in situ kinetic changes and in situ inactivation of PPO at low temperatures.

A considerable reduction was observed in the $K_{\mathrm{m}}$ of PPO when potatoes were heated at $50{ }^{\circ} \mathrm{C}$ for $75 \mathrm{~min}$. The reduction in $K_{\mathrm{m}}$ was sharper when enzyme extracts were obtained by changing the extraction mixture (EM1), partial purification $\left(0-90 \%\left(\mathrm{NH}_{4}\right)_{2} \mathrm{SO}_{4}\right.$ precipitation) and dialysis $(44 \mathrm{~h})$ conditions. This drastic change in $K_{\mathrm{m}}$ clearly explained the increase in PPO activity when heating time was extended. The $V_{\max }$ and $V_{\max } / K_{\mathrm{m}}$ values of PPO from potatoes heated for $75 \mathrm{~min}$ were also higher than those of PPO from potatoes heated for $60 \mathrm{~min}$, but lower than those of PPO from controls. The appearance of internal softening and browning on peel during heating at $50{ }^{\circ} \mathrm{C}$ and activation of PPO occurred at the same time. Thus, softening possibly allowed the diffusion of some activators from vacuoles or from other cell compo- nents to the locations of PPO and contact of the enzyme with those agents under mild heating conditions caused the modification of the enzyme's structure and related kinetic properties. It seems that the activation was not due to the release of some other latent PPO forms. This is because we did not observe a significant increase in PPO's $V_{\max }$ value that is related to enzyme concentration. The drop in our $K_{\mathrm{m}}$ value was also very sharp and such a drastic change needs the activation of a considerable amount of latent forms with relatively low $K_{\mathrm{m}}$ values. These results and explanations were in line with those of Rodriguez-Lopez et al. [21] who also reported a sharp drop in the $K_{\mathrm{m}}$ of crude mushroom PPO activated during heating. The apparent activation of enzyme suggested that in a LTB process, which aims to control PPO activity, the limits of heating should be determined by monitoring the activity of this enzyme and finding the time of its activation.

\section{Effect of heating on LOX}

Heating at $50{ }^{\circ} \mathrm{C}$ for 45 min caused a slight activation of LOX (Table 3). Thus, unlike PPO activation, LOX activation was not related to the thermal softening which had appeared by $75 \mathrm{~min}$ heating. Heating for 60 or 75 min caused only a slight reduction in crude enzyme activity. However, we detected considerable changes in the kinetic characteristics of enzyme obtained from $60 \mathrm{~min}$ heated potatoes. The sharp reduction of its $K_{\mathrm{m}}$ by heating made LOX more reactive to its substrate at its low concentrations (Fig. 3). However, the reduction of the enzyme's $V_{\max }$ indicated that activation and inactivation of LOX occurred at the same time. This explains why LOX activation did not cause an apparent increase in enzyme activity. In general, plant LOX is a monomeric enzyme located in the cytoplasm and/or in subcellular 
Table 4 Activities of pectin methylesterases $(P M E)$ from control and low temperature blanched potatoes

\begin{tabular}{|c|c|c|c|c|c|}
\hline $\begin{array}{l}\text { Heating time at } \\
50^{\circ} \mathrm{C}(\mathrm{min})\end{array}$ & \multicolumn{4}{|c|}{ Ionically+Soluble PME } & $\begin{array}{l}\text { Covalently } \\
\text { bound PME } \\
\text { Activitya }(\mathrm{U})^{\text {action }}\end{array}$ \\
\hline Control & $268 \pm 10$ & $284 \pm 11$ & $152 \pm 15$ & $161 \pm 16$ & $26 \pm 0.8$ \\
\hline 45 & $\begin{array}{l}243 \pm 8 \\
(-9 \%)^{\mathrm{c}}\end{array}$ & $\begin{array}{l}287 \pm 10 \\
(+1 \%)\end{array}$ & $\begin{array}{l}128 \pm 14 \\
(-16 \%)\end{array}$ & $\begin{array}{l}151 \pm 16 \\
(-6 \%)\end{array}$ & $\begin{array}{l}29 \pm 1.2 \\
(+12 \%)\end{array}$ \\
\hline 75 & $\begin{array}{l}221 \pm 4 \\
(-18 \%)\end{array}$ & $\begin{array}{l}238 \pm 4 \\
(-16 \%)\end{array}$ & $\begin{array}{l}142 \pm 24 \\
(-7 \%)\end{array}$ & $\begin{array}{l}153 \pm 26 \\
(-5 \%)\end{array}$ & $\begin{array}{l}30 \pm 2 \\
(+15 \%)\end{array}$ \\
\hline
\end{tabular}

a Assayed by the titrimetric method

${ }^{b}$ Assayed by the spectrophotometric method

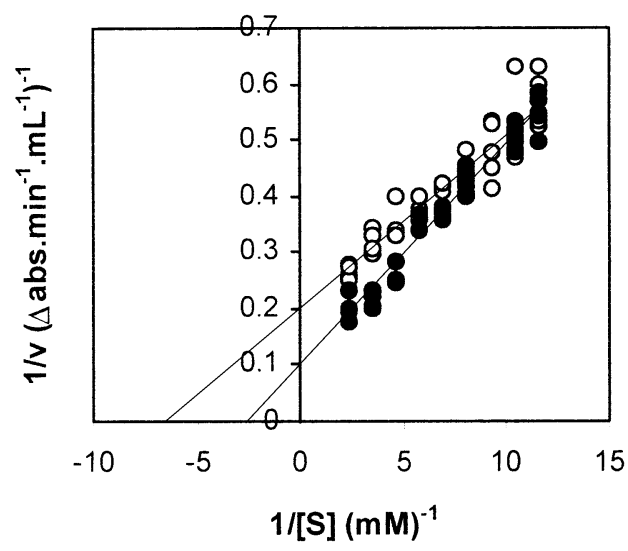

Fig. 3 Double reciprocal plots for partially purified lipoxygenase from control and low temperature blanched potatoes. White circles $50^{\circ} \mathrm{C} / 60 \mathrm{~min}$, black circles control

organelles and it can be activated readily by $\mathrm{Ca}^{2+}$ ions $[22,23]$. Thus, the increased reactivity of LOX might be attributed to its contact with $\mathrm{Ca}^{2+}$, which may be released from starch during heating [9]. The activation of LOX may cause the formation of off flavours, degradation of some nutrients or acceleration of the exhaustion of anti-browning agents (antioxidants) during the storage of minimally processed potatoes. Therefore, it may be a handicap for the control of potato PPO by LTB. However, It is worth noting that the activation of potato LOX may be desirable for biotechnological purposes. Potato LOX is different from the other plant LOX in its unique capability to oxidise 20 carbon atom polyunsaturated fatty acids. Thus, biotechnologists consider this enzyme as an alternative to mammalian LOX which may be used for the production of hydroperoxide precursors of some biologically active compounds [24].

\section{Effect of heating on PME}

Heating at $50{ }^{\circ} \mathrm{C}$ for $45 \mathrm{~min}$ slightly activated covalently bound PME, whereas 60 min heating caused significant
${ }^{\mathrm{c}}$ Indicates the percentage change in activity or specific activity as compared to the corresponding control

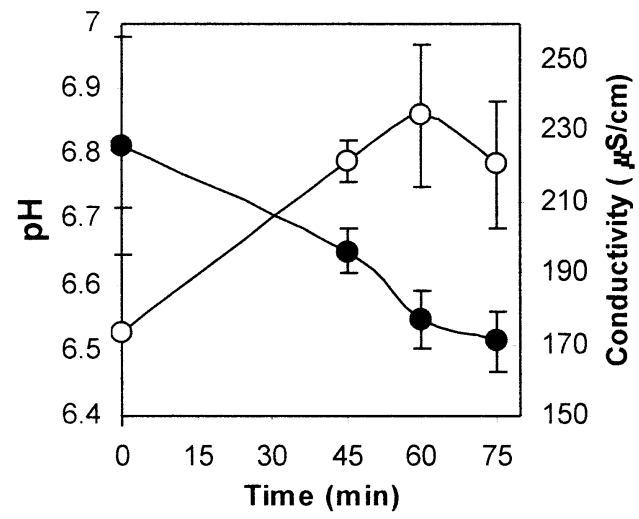

Fig. 4 The effect of low temperature blanching on conductivity (white circles) and $\mathrm{pH}$ (black circles) of potato extracts

activation of enzyme and increased its activity almost 1.4-fold (Table 4). Bartolome and Hoff [25] reported that heat activation of covalently bound cell wall PME occurred by the contact of enzyme with intracellular electrolytes. However, these researchers believed that this contact occurred in the $60-70{ }^{\circ} \mathrm{C}$ range where cellular membranes (plasmalemma) lose their integrity. Our conductivity measurements in potato extracts showed that heating caused almost $27-35 \%$ increase in the conductivities of heated potato extracts as compared to those of controls (Fig. 4). Heating apparently increased the permeability of cell wall membranes and this caused the leakage of more ions from potato cells. Thus, our results showed that activation of covalently bound cell wall PME is possible at lower temperatures. The activity of ionically bound+soluble PME in potatoes is considerably higher than the activity of covalently bound PME. However, heating at $50{ }^{\circ} \mathrm{C}$ did not activate this enzyme fraction. The apparent $\mathrm{pH}$ drop in potato extracts in the first hour of heating indicated the contact of PME with pectic compounds. Thus, it seemed that heat treatment at $50{ }^{\circ} \mathrm{C}$ might be beneficial in improving the texture of minimally processed potatoes. 
In conclusion, LTB of whole potatoes at $50{ }^{\circ} \mathrm{C}$ may be used to reduce PPO activity and to reduce the affinity of PPO to its substrate. Overheating caused the significant activation of PPO and softening. Thus, limits of heating should be determined by monitoring the activity of PPO enzyme and potato firmness. Heating at $50{ }^{\circ} \mathrm{C}$ also activated covalently bound PME enzyme and this may be beneficial to improve the texture of potatoes. The activation of LOX during heating is a handicap of LTB.

Acknowledgements This work has been funded by the Research Foundation of İzmir Institute of Technology, Turkey. (Grant $\neq$ 1999 Müh 05). We thank to Mr. Selçuk Taşkin, general manager of Lamb-Weston-Doğuş potato processing plant, for supplying the potatoes used in this study.

\section{References}

1. Gunes G, Lee CY (1997) J Food Sci 62:572-575,582

2. Sapers GM, Miller RL (1992) J Food Sci 57:1132-1135

3. Santerre CR, Leach TF, Cash JN (1991) J Food Sci 56:257259

4. Sapers GM, Miller RL (1993) J Food Sci 58:1076-1078

5. Sapers GM, Miller RL (1995) J Food Sci 60:762-766, 776

6. Kim DM, Smith, NL, Lee, CY (1993) J Food Sci 58:11111114,1124

7. Valle JMD, Aranguiz V, Leon H (1998) Food Res Int 31:557-569
8. Yemenicioğlu A, Özkan M Cemeroğlu B (1997) J Food Sci 62:508-510

9. Andersson A, Gekas V, Lind I, Oliveira F, Öste R (1994) Crit Rev Food Sci 34:229-251

10. Ranganna B, Raghavan GSV, Kushalappa AC (1998) Postharvest Biol Technol 13:215-223

11. Rackis JJ, Honig DH, Sessa DJ, Moser, HA (1972) Cereal Chem 49:586-597

12. Hagerman AE, Austin PJ (1986) J Agric Food Chem 34: 440-444

13. Yemenicioğlu A, Cemeroğlu B (1999) Z. Lebensm. Unters. Forsch 208:369-372

14. Harris DA (1987) Spectrophotometry and spectrofluorometry In: Harris DA, Bashford CL (eds) Spectrophotometric assays. IRL, Oxford, pp 59-60

15. Mittal GS (1994) Z Lebensm Wiss Technol 27:253-258

16. Vamos-Vigyazo L (1981) Crit Rev Food Sci 15:49-127

17. Batistuti, Lourenço (1985) Food Chem. 18:251-263

18. Gomes MRA, Ledward DA (1996) Food Chem 56:1-5

19. Barbosa-Canovas GV, Pothakamury UR, Palou E, Swanson BG (1998) Nonthermal preservation of foods. Dekker, New York

20. Cho YK, Ahn HK (1999) J Food Biochem 23:577-592

21. Rodriguez-Lopez JN, Fenoll LG, Devece C, SanchezHernandez D, Reyes EDL, Garcia-Canovas F (1999) J Agric Food Chem 47:3028-3035

22. Restrepo F, Snyder HE, Zimmerman GL (1973) J Food Sci 38:779-782

23. Klein BP (1976) J Agric Food Chem 24:938-942

24. Aziz S, Wu Z, Robinson DS (1999) Food Chem 64:227-230

25. Bartolome LG, Hoff JE (1972) J Agric Food Chem 20:266270 